\title{
POPULASI DAN INTENSITAS SERANGAN Paraeucosmetus pallicornis PADA TANAMAN PADI DI KABUPATEN MNAHASA SELATAN
}

\section{POPULATION AND ATTACKING INIENSITY OF Paraeucosmetus pallicornis IN SOUTH MNAHASA REGENCY}

\author{
Christian L Kaparang'), J. Pelealu²), dan Ch.L Salaki2) \\ 1) UPTD Balai Benih Tanaman Pangan Dan Hortikultura. Dinas Pertanian dan Peternakan Provinsi Sulawesi \\ Utara (email : christiankaparang@yahoo.com) \\ 2) Jurusan Hama dan Penyakit Tumbuhan Fakultas Pertanian, Universitas Sam Ratulangi Manado-95115
}

\begin{abstract}
The study aimed to determine the population and attacking intensity of Paraeucosmetus pallicornis on rice based on the altitude in South Minahasa regency. Stratified sampling method was conducted consisting of three strata namely 0-300 meters above sea level, $>300-600$ meters above sea level, and $>600$ meters above sea level. Sampling was collected by taking the diagonal of each 10 clump at different levels of plant age. The results showed that the highest average populations density of $P$. pallicornis was found at altitude $>600 \mathrm{~m}$ above sea level. That was equal to 6.46 individuals per clump. In the altitude of $0-300$ meters above sea level, average populations density was 6.07 individuals per clump. The lowest population was detected at altitude $>300-600$ meters above sea level which was 6.03 individuals per clump. The attacking intensity of $P$. pallicornis was the highest at an altitude of 0 300 meters above sea level that is equal to $25.87 \%$ per clump, followed by the altitude $>300-600$ meters above sea level which was $24.12 \%$ per clump. The lowest was an altitude of $>600$ meters above sea level $23.77 \%$ which was per clump.
\end{abstract}

Keywords: rice, Paraeucosmetus pallicornis

\section{ABSTRAK}

Penelitian bertujuan untuk mengetahui padat populasi dan intensitas serangan Paraeucosmetus pallicornis pada tanaman padi berdasarkan ketinggian tempat di Kabupaten Minahasa Selatan. Penelitian menggunakan Metode Stratified Sampling yang terdiri dari 3 strata ketinggian tempat yaitu, 0-300 meter di atas permukaan laut (dpl), >300-600 dpl, dan $>600 \mathrm{dpl}$. Pengambilan sampel dilakukan secara diagonal dengan mengambil masing-masing 10 rumpun pada berbagai tingkat umur tanaman. Hasil penelitian menunjukkan bahwa rata-rata padat populasi $P$. pallicornis tertinggi dijumpai pada ketinggian $>600$ meter dpl yaitu sebesar 6,46 ekor per rumpun, diikuti ketinggian 0-300 meter dpl mencapai 6,07 ekor per rumpun, dan populasi terendah terdapat pada ketinggian $>300-600$ meter dpl mencapai 6,03 ekor per rumpun. Intensitas serangan $P$. pallicornis pada tanaman padi tertinggi ditemukan pada ketinggian 0-300 meter dpl yaitu sebesar 25,87\% per rumpun, diikuti ketinggian 300$600 \mathrm{dpl}$ mencapai $24,12 \%$ per rumpun, dan terendah pada ketinggian $>600$ meter dpl mencapai $23,77 \%$ per rumpun.

Kata Kunci : tanaman padi, Paraeucosmetus pallicornis

Eugenia Volume 17 No. 3 Desember 2011 


\section{PENDAHULUAN}

Pembangunan pertanian di Indonesia bertujuan untuk meningkatkan produksi demi kesejahteraan masyarakat. Peningkatan produksi dirasakan sangat perlu untuk memenuhi kebutuhan penduduk yang semakin meningkat. Selain itu, peningkatan produksi pertanian bertujuan untuk mengurangi impor bahan makanan, juga meningkatkan devisa dalam rangka mendukung pembangunan nasional.

Beras merupakan bahan makanan pokok bagi penduduk Indonesia, karena sebagian besar mengkonsumsinya sebagai sumber karbohidrat, sehingga beras menjadi komoditi strategis. Kekurangan persediaan beras dapat mengganggu stabilitas negara, terutama pada aspek keamanan dan sosial ekonomi.

Kegiatan program peningkatan produksi beras menyebabkan naiknya produksi di beberapa daerah penghasil beras utama di Indonesia, seperti Jawa Barat, Jawa Tengah, Jawa Timur, Sumatera Selatan dan Sulawesi Selatan. Rata-rata kenaikan produksi untuk tiga tahun terakhir mencapai 3,78\%; dengan produksi nasional mencapai 66,41 juta ton pada tahun 2010 (Suswono, 2010).

Produktifitas tanaman padi di Sulawesi Utara rata-rata 5.02 ton per hektar, sedangkan produksi nasional 6,52 ton per hektar. Hal ini menunjukkan bahwa rata-rata produksi padi di Sulawesi Utara masih rendah (Anonim 2011). Rendahnya produksi padi di Sulawesi Utara disebabkan oleh beberapa hal diantaranya, petani pada umumya tidak menanam benih padi bermutu dan bersertifikasi, sistem budidaya tanaman belum optimal, dan terdapatnya serangan hama dan penyakit. Serangan hama pada tanaman padi relatif tinggi setiap tahun. Serangan tersebut belum dapat dikendalikan secara optimal, sehingga mengakibatkan kerugian yang cukup besar baik kehilangan hasil, menurunnya mutu, terganggunya kontinunitas produksi, serta menurunnya pendapatan petani. Masalah hama dan penyakit yang semakin kompleks dirasakan oleh petani dari tahun ketahun, hal ini diduga akibat dampak perubahan iklim global yang berpengaruh terhadap pola musim/cuaca lokal yang sangat erat kaitannya dengan perkembangan hama. Disamping itu, permasalahan hama dan penyakit pada tanaman padi akan terus dihadapi karena luas lahan yang semakin berkurang, penggarap yang bukan pemilik, terbatasnya modal, pengetahuan dan keterampilan petani, permasalahan irigasi, pasar serta harga produksi (Gaib, 2011).

Di Sulawesi Utara terdapat beberapa serangga hama utama pada tanaman padi diantaranya: penggerek batang padi putih (Scirpophaga innotata), ulat grayak (Spodoptera litura), walang sangit (Leptocorisa oratorius), wereng hijau (Nepottetix virescens), dan hama putih (Nympula depunctalis). Beberapa tahun terakhir berkembang serangan hama minor yaitu kepinding tanah (Scotinophara coartata) (Anonim, 2011; Kalshoven, 1981; Suharto, 2007). Pelealu (1991), menyatakan bahwa terdapat serangga hama Paraeucosmetus sp. yang menyerang tanaman padi, yaitu pada bulir padi di daerah Toraud Kabupaten Bolaang Mongondow. Watung (1996) mengemukakan bahwa ditemukan Paraeucosmetus sp. yang hidup dan menyerang tanaman padi serta rumput paspalum (Paspalum conjugatum Berg) di Kecamatan Tumpaan Kabupaten Minahasa.

Akhir-akhir ini di beberapa daerah Provinsi seperti Gorontalo, Kalimantan Timur, bahkan di Kabupaten Manggarai (NTT) dilaporkan adanya serangan hama baru kepik penghisap bulir padi, yang sering disebut kepik hitam atau semut hitam (karena adanya kemiripan bentuk). Di Sulawesi Selatan khususnya di Kabupaten Pinrang ditemukan serangan kepik hitam yang menghisap bulir padi, mengakibatkan padi menjadi hampa, jika masih ada yang dipanen tidak laku terjual karena beras setelah digiling berwarna hitam dan terasa pahit (Risnandi, 2011). Hasil kunjungan Tim dari IPB (Prof. Dr Aunu Rauf), Unsrat (Prof. Dr Ir. Jantje Pelealu), BPTPH Sulut (Imran), BBPOPT (Harsono Lanya) di wilayah Kabupaten Minahasa Selatan, khususnya di Desa Matani dan Popontolen Kecamatan Tumpaan (November, 2009), melaporkan pada pertanaman padi fase generatif, rerumputan di galengan dan tepi Sungai Kwarter ditemukan populasi $P$. pallicornis cukup tinggi. Luas hamparan sekitar 5 ha, populasi $2-20$ ekor per rumpun dengan tingkat serangan 50 persen. 
Informasi yang diperoleh dari petugas pengamat hama di lapangan, mengatakan bahwa populasi $P$. pallicornis telah menyebar di beberapa lokasi sentra produksi padi di Kabupaten Minahasa Selatan. Berdasarkan hal tersebut maka perlu dilakukan penelitian tentang populasi dan intensitas serangan $P$. pallicornis pada tanaman padi di Kabupaten Minahasa Selatan.

Penelitian bertujuan untuk mengetahui populasi dan intensitas serangan $P$. palicornis pada tanaman padi berdasarkan ketinggian tempat dan tingkat umur tanaman di Kabupaten Minahasa Selatan.

\section{METODE PENEUTIAN}

Penelitian dilaksanakan pada tanaman padi sawah di Kabupaten Minahasa Selatan selama tujuh bulan. Pelaksanaan penelitian dimulai sejak bulan Mei sampai dengan Desember 2011.

Bahan dan alat yang digunakan dalam penelitian ini adalah Paraecosmetus pallicornis, kurungan serangga, alkohol $70 \%$, pisau, cutter, kertas label, pinset, loupe, hand counter, termometer, aspirator dan alat tulis menulis.

Penelitian menggunakan Metode Stratified Sampling pada tiga strata ketinggian tempat di Kabupaten Minahasa Selatan, yaitu ketinggian 0300 meter dpl (Kecamatan Tumpaan, Desa Popontolen), ketinggian $>300-600$ meter dpl (Kecamatan Ranoyapo, Desa Ranoyapo) dan ketinggian >600 meter dpl (Kecamatan Tompasobaru, Desa Tumani). Pada masing-masing lokasi sampel diletakkan termometer untuk mengetahui keadaan temperatur pada saat pengamatan/pengambilan sampel.

Pengambilan sampel dilakukan secara diagonal pada lokasi sampel yaitu pada setiap sudut dan bagian tengah areal pertanaman padi (sublokasi sampel) yang masing-masing diambil sebanyak 10 rumpun. Pengambilan sampel dilakukan sebanyak 3 kali dengan interval waktu 10 hari yang dimulai pada tanaman berumur 51 hari setelah tanam (hst), 61 hst, dan 71 hst.

Pengamatan populasi $P$. pallicornis dilakukan dengan menggunakan kurungan serangga berukuran $40 \mathrm{~cm} \times 120 \mathrm{~cm}$ yang terbuat dari kawat sebagai kerangka dan ditutupi dengan kain kasa. Ku- rungan diletakkan pada rumpun tanaman sampel kemudian tanaman ditepuk-tepuk agar serangga turun ke bagian bawah rumpun tanaman padi. $P$. pallicornis yang terkumpul di bagian bawah tanaman padi, dihitung dengan menggunakan hand caunter. Untuk mengetahui populasi $P$. pallicornis dilakukan dengan menggunakan rumus sebagai berikut :

$$
\mathrm{P}=\frac{\mathrm{a}}{\mathrm{b}}
$$

Keterangan :

$\mathrm{P}=$ padat populasi

$\mathrm{a}=$ jumlah sampel yang ditemukan

$\mathrm{b}=$ jumlah pengamatan (Anonim, 2008)

Pengamatan intensitas serangan dilaksanakan setelah selesai menghitung populasi $P$. pallicornis pada rumpun yang sama. Intensitas serangan ditunjukkan dengan adanya kerusakan bulir pada malai tanaman padi. Gejala serangan $P$. pallicornis yaitu terdapatnya bintik hitam bekas tusukan stilet dan terjadinya perubahan warna bulir menjadi coklat kehitaman. Untuk menghitung intensitas serangan digunakan rumus:

$$
\begin{aligned}
& I=\frac{a}{a \cdot b} \times 100 \% \\
& \text { keterangan : } \\
& I=\quad \text { intensitas serangan } \\
& a=\text { jumlah malai yang rusak } \\
& b=\quad \text { jumlah malai dalam satu rumpun (Wasiati, } \\
& \text { 2009) }
\end{aligned}
$$

\section{Analisa Data}

Data yang diperoleh pada masing-masing pengamatan dianalisis dengan menggunakan annova dan apabila terdapat perbedaan nyata dilanjutkan uji BNT.

\section{HASIL DAN PEMBAHASAN}

\section{Populasi Paraeucosmetus pallicornis}

Hasil penelitian ternyata $P$. pallicornis ditemukan pada berbagai ketinggian tempat di Kabupaten Minahasa Selatan dengan populasi yang beragam pada berbagai tingkat umur tanaman padi. Data populasi $P$. pallicornis di Kabupaten Minahasa Selatan selengkapnya dapat dilihat pada Tabel 1. 
Tabel 1. Populasi P. pallicornis di Kabupaten Minahasa Selatan

(Table 1. Population of P. pallicornis in South Minahasa Regency)

\begin{tabular}{cccccc}
\hline $\begin{array}{c}\text { Ketinggian Tempat } \\
\text { (meter dpl.) }\end{array}$ & 51 hst & 61 hst & 71 hst & Jumlah & Rata-rata \\
\cline { 2 - 6 } & 2,1 & 4,9 & 11,2 & 18,2 & 6,06 \\
$>0-300$ & 2,4 & 5,5 & 10.2 & 18,1 & 6,03 \\
$>300-600$ & 1,4 & 5,2 & 12.8 & 19,4 & 6,46 \\
\hline 600 & 5.9 & 15,6 & 34,2 & 55,7 & \\
\hline Total & & & & &
\end{tabular}

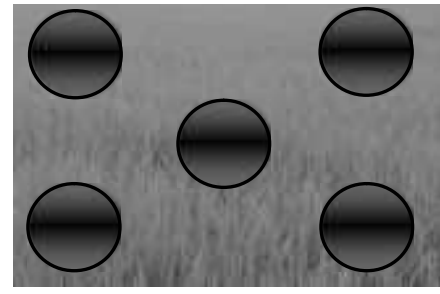

Keterangan :

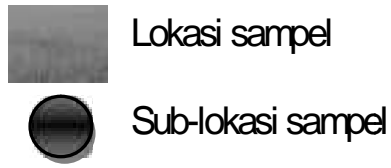

Gambar 1. Teknik Pengambilan Sampel Secara Diagonal

(Figure 1. Diagonal Sampling Technique)

Melihat Tabel 1, ternyata populasi $P$. pallicornis merata pada berbagai strata ketinggian, sedangkan rata-rata populasi $P$. pallicornis berdasarkan tingkat umur tanaman tertinggi berturut-turut pada tanaman berumur 71 hari setelah tanam (hst) mencapai 34, 2 individu, kemudian 61 hst mencapai 15,6 individu, dan 51 hst mencapai 5,9 individu.

Relatif tingginya populasi $P$. pallicornis pada umur tanaman padi 71 hst diduga karena di sekitar areal lokasi sampel terdapat tanaman padi sudah mulai dipanen sehingga diduga terjadi migrasi $P$. pallicornis dari tanaman padi yang sudah mulai dipanen ke lokasi tanaman sampel.

Rauf (2010) melaporkan bahwa perkembangan $P$. pallicornis berlangsung mengikuti fase pertumbuhan tanaman padi. Selanjutnya, Watung (1996) mengemukakan bahwa waktu migrasi terjadi di pagi hari atau menjelang malam hari, biasanya bergerombol dan melewati rerumputan pematang sawah. Terdapatnya hamparan tanaman padi fase generatif atau matang susu dan menjelang panen di sekitar lokasi sampel memberikan peluang bagi $P$. pallicornis untuk bermigrasi ke tanaman sampel.

Pelealu (1991) dan Watung (1996) menyatakan bahwa nimfa $P$. pallicornis instar I dan II hidup pada tanaman padi fase vegetatif dengan cara menghisap cairan permukaan batang padi. Nimfa instar III, IV, V dan imago hidup pada tanaman padi fase generatif, dan mengambil makanan dengan cara menghisap cairan bulir tanaman padi.
Hasil analisis statistik terhadap populasi pada ke tiga strata ketinggian menunjukkan tidak ada perbedaan yang nyata, seperti terlihat pada Tabel 2. Pada tabel tersebut menunjukkan bahwa tidak terdapat perbedaan yang nyata terhadap populasi $P$. pallicornis pada ke tiga strata ketinggian, hal ini diduga karena faktor budidaya tanaman dan teknik pengendalian hama yang dilakukan oleh petani.

Hasil komunikasi dengan petani baik di Desa Popontolen, Kecamatan Tumpaan (ketinggian 0-300 meter dpl), di Desa Ranoyapo, Kecamatan Ranoyapo (ketinggian $>300-600$ meter dpl), dan di Desa Tumani, Kecamatan Tompasobaru (ketinggian >600 meter dpl) bahwa umumnya pola tanam yang dilakukan adalah penanaman yang tidak serempak. Sulitnya menjalankan program penanaman serentak oleh petani disebabkan karena masalah ketersediaan air. Haerudin (2009) menyatakan bahwa salah satu penyebab tidak serempaknya pola tanam padi di Indonesia adalah ketersediaan air. Ketersediaan air dipengaruhi oleh kondisi saluran air primer, sekunder, dan tersier yang tidak terawat. Selanjutnya Untung (1993) mengungkapkan, pola tanam padi yang tidak seragam dapat menyebabkan hama berpindah-pindah dari tanaman satu ke tanaman lainnya dan merusak bagian tanaman yang diinginkannya. 
Kaparang, Ch.L., dkk. : Populasi dan Intensitas Serangan

Tabel 2. Hasil Analisis Statistik Populasi P. pallicornis di Kabupaten Minahasa Selatan

(Table 2. The Results of Statistical Analysis of Populations of P. pallicornis in South Minahasa Regency)

\begin{tabular}{ccc}
\hline $\begin{array}{c}\text { Ketinggian Tempat } \\
\text { (meter dpl.) }\end{array}$ & Populasi (individu/rumpun) & Notasi \\
\hline $0-300 \mathrm{M} \mathrm{dpl}$ & 6,07 & $\mathrm{a}$ \\
$>300-600 \mathrm{M} \mathrm{dpl}$ & 6,03 & $\mathrm{a}$ \\
$>600 \mathrm{M} \mathrm{dpl}$ & 6,47 & $\mathrm{a}$ \\
\hline
\end{tabular}

\section{Intensitas Serangan Paraeucosmetus pallicornis}

Hasil penelitian ternyata intensitas serangan $P$. pallicornis pada berbagai ketinggian tempat di Kabupaten Minahasa Selatan adalah merata namun beragam pada berbagai tingkat umur tanaman padi. Data intensitas serangan $P$. pallicornis di Kabupaten Minahasa Selatan selengkapnya dapat dilihat pada Tabel 3 .

Tabel 3 terlihat bahwa rata-rata intensitas serangan $P$. pallicornis merata pada ke tiga strata ketinggian, namun bervariasi pada berbagai tingkat umur tanaman yang tertinggi ditemukan pada tanaman berumur 71 hst yakni mencapai rata-rata 115,6 persen, kemudian tanaman berumur 61 hst mencapai 70,8 persen, dan tanaman berumur 51 hst mencapai 21,2 persen.

Tingginya intensitas serangan pada tanaman padi umur 71 hst diduga disebabkan karena populasi $P$. pallicornis pada tanaman sampel yang sama lebih tinggi dibandingkan dengan sampel umur tanaman lainnya. Rondonuwu (2007) menyatakan bahwa intensitas kerusakan pada umumnya mengikuti keadaan populasi organisme penyebab kerusakan. Makin tinggi populasi organisme pengganggu tanaman maka semakin besar kerusakan yang ditimbulkannya. Huffaker and Messenger (1976) menyatakan bahwa beberapa jenis serangga dapat menyebabkan kerusakan yang sangat serius walaupun populasinya di alam sedikit. Tingginya kerusakan tanaman oleh organisme pengganggu tanaman dapat dipengaruhi oleh populasi dan kemampuan merusak dari organisme tersebut. Kalshoven (1981) menyatakan bahwa serangga vektor penyakit seperti hama wereng kerusakan akibat tusukan alat mulutnya terhadap bagian tanaman tidak berarti dibandingkan jenis virus yang ditularkan yang dapat mengakibatkan puso.

Hasil analisis statistik intensitas serangan $P$. pallicornis pada ke tiga strata ketinggian menunjukkan tidak ada perbedaan yang nyata, seperti terlihat pada Tabel 4. Pada tabel tersebut menunjukkan bahwa hasil analisis intensitas serangan $P$. pallicornis berbagai ketinggian di Kabutapen Minahasa Selatan tidak terdapat perbedaan yang nyata. Hal ini diduga karena pengaruh pola tanam yang dilakukan oleh petani yaitu sistem pertanian monokultur dari tahun ke tahun.

Tabel 3. Rata-rata Intensitas Serangan P. pallicornis di Kabupaten Minahasa Selatan

(Table 3. The Average Intensity of the Attacks P. pallicornis in South Minahasa Regency)

\begin{tabular}{cccccc}
\hline \multirow{2}{*}{$\begin{array}{c}\text { Ketinggian Tempat } \\
\text { (meter dpl) }\end{array}$} & 51 hst & 61 hst & 71 hst & Jumlah & Rata-rata \\
\cline { 2 - 6 } & 7,5 & 31,5 & 38,6 & 77,6 & 25,87 \\
$300-300$ & 9,1 & 28,3 & 35,2 & 72,6 & 24,12 \\
$>600$ & 4,6 & 19,6 & 47,1 & 71,3 & 23,77 \\
\hline Total & 21,2 & 70,8 & 115,6 & 221,5 & \\
\hline
\end{tabular}

Tabel 4. Hasil Analisis Statistik Intensitas Serangan P. pallicornis di Kabupaten Minahasa

(Table 4. The Results of Statistical Analysis of the Attack Intensity of P. pallicornis in Minahasa Regency)

\begin{tabular}{ccc}
\hline Ketinggian Tempat & Intensitas serangan (rumpun) & Notasi \\
\hline $0-300 \mathrm{M} \mathrm{dpl}$ & 25,9 & a \\
$>300-600 \mathrm{M} \mathrm{dpl}$ & 24,1 & a \\
$>600 \mathrm{M} \mathrm{dpl}$ & 23,2 & $\mathrm{a}$ \\
\hline
\end{tabular}


Tabel 5. Kategori Serangan P. pallicornis di Kabupaten Minahasa Selatan

(Table 5. Categories of Attacks P. pallicornis in South Minahasa Regency)

\begin{tabular}{|c|c|c|c|c|c|c|}
\hline \multirow{3}{*}{$\begin{array}{l}\text { Ketinggian Tempat } \\
\text { (meter dpl) }\end{array}$} & \multicolumn{6}{|c|}{ Intensitas Serangan/Kategori Serangan/umur tanaman } \\
\hline & \multicolumn{2}{|c|}{51 hst. } & \multicolumn{2}{|c|}{61 hst. } & \multicolumn{2}{|c|}{71 hst. } \\
\hline & I.S & K.S & I.S & K.S & I.S & K.S \\
\hline $0-300$ & 7,5 & ringan & 31,5 & sedang & 38,6 & sedang \\
\hline $300-600$ & 9,1 & ringan & 38,3 & sedang & 35,2 & sedang \\
\hline$>600$ & 4,6 & ringan & 19,6 & ringan & 47,1 & sedang \\
\hline
\end{tabular}

Keterangan :

Kategori serangan : Ringan = 1 sampai dengan $25 \%$

Sedang $=26$ sampai dengan $50 \%$

Berat = 51 sampai dengan $80 \%$

Puso $=>80 \%$ (Wasiati, 2007)

Varietas padi yang dibudidayakan baik pada ketinggian 0-300 dpl, >300-600 dpl, dan >600 dpl adalah varietas Sultan dan pada umumnya ditanam secara monokultur dari tahun ke tahun. Pada ketinggian 0-300 dpl varietas Sultan telah ditanam selama enam kali berturut-turut, sedangkan diketinggian $>300-600$ dpl ditanam empat kali berturutturut, serta di ketinggian $>601$ dpl ditanam tiga kali berturut-turut.

Umumnya varietas tanaman padi yang telah dilepas dan tersertifikasi mempunyai ketahanan terhadap serangan hama, namun ketahanan varietas padi akan menurun terhadap serangan hama apabila ditanam secara berulang-ulang pada tempat yang sama. Dilain pihak serangga hama pada awalnya tidak mampu menyerang varietas padi tersebut tetapi akhirnya dapat mematahkan ketahanan karena ditanam berulang-ulang. Untung (1993), menyebutkan bahwa varietas padi yang ditanam secara terus-menerus pada tempat sama akan merugikan varietas tersebut. Salah satu kerugian yang akan dialami adalah menurunnya daya tahan tanaman dari serangan hama. Selanjutnya, Sembel (2010), menyatakan bahwa tanaman yang dibudidayakan sepanjang tahun tanpa adanya rotasi dengan tanaman lain maka secara fisiologis akan mudah diserang oleh hama. Demikian pula yang terjadi pada ketinggian 0-300 dpl, >300-600 dpl, dan $>600$ dpl di Kabupaten Minahasa Selatan dengan menanam varietas Sultan secara terus-menerus sepanjang tahun, tanpa pergantian varietas atau tanaman lainnya.
Sesuai buku petunjuk rekomendasi pengamatan dan pengendalian tanaman pangan yang dikeluarkan Direktorat Perlindungan Tanaman Pangan tahun 2009, maka hasil pengamatan intensitas serangan $P$. pallicornis pada tanaman padi umur 51 hst, 61 hst, dan 71 hst. berdasarkan ketinggian 0-300 dpl, >300-600 dpl, dan >600 dpl dimasukkan dalam kategori serangan sesuai Tabel 5 .

Tabel 5 terlihat intensitas serangan $P$. pallicornis umur tanaman padi $51 \mathrm{hst}$, pada ketinggian 0-300 dpl, >300-600 dpl, dan >600 dpl. Kategori serangan ringan. Sedangkan pada umur tanaman padi 71 hst. kategori serangan bervariasi berdasarkan ketinggian. Pada ketinggian 0-300 dpl kategori serangan sedang; ketinggian $>301-600 \mathrm{dpl}$, dan >601 dpl kategori serangan ringan. Pada umur tanaman padi $71 \mathrm{hst}$ intensitas serangan berdasarkan ketinggian 0-300 dpl, >300-600 dpl, dan >600 dpl kategori serangan sedang.

\section{KESIMPULANDANSARAN}

Paraeucosmetus pallicornis pada tanaman padi, telah tersebar secara merata pada berbagai strata ketinggian tempat di Kabupaten Minahasa Selatan dengan populasi tertinggi pada tanaman berumur 71 hari setelah tanam (hst) dan terendah pada tanaman berumur 51 hst. Intensitas serangan P. pallicornis pada tanaman padi di Kabupaten Minahasa Selatan mengikuti populasi hama.

Perlu dilakukan penelitian lanjutan untuk mengetahui jenis-jenis varietas tanaman padi yang 
tahan terhadap serangan $P$. pallicornis di Kabupaten Minahasa Selatan.

\section{DAFTARPUSTAKA}

Anonim, 2008. Laporan Tahunan. Balai Perlindungan Tanaman Pangan dan Hortikultura Provinsi Sulawesi Utara. Manado. , 2011. Laporan Tahunan. Dinas'Pertanian dan Peternakan Provinsi Sulawesi Utara. Manado.

Direktorat Perlindungan Tanaman Pangan. 2009. Rekomendasi Pengendalian Organisme Pengganggu Tanaman Pangan. Jakarta.

Gaib, S. 2011. Dampak Perobahan Iklim dan Perkembangan Organisme Pengganggu Tanaman. Materi TOT SL-Iklim Direktorat Jenderal Perlindungan Tanaman Pangan. PNPM-Jakarta.

Haerudidin, T. 1999. Bercocok Tanam Padi Sawah. Buku 2 : Pusdiklat Tanaman Pangan; Bogor.

Huffaker, C. B. and P. S. Messenger. 1976. Theory and Practice of Biological Control. Academic Press. Inc, London.

Kalshoven, L.G.E. 1981. Pests of crop in Indonesia. Revised and translatet by P.A, van der laan, University of Amsterdam with the assistance of G.H.L. Rothchild, CSIRO, Canberra. P.T. Ichtiar Baru-van houve, Jakarta.

Pelealu, J. 991. Bionomi Paraeucosmetus sp. (Hemiptera: Lygaeidae) pada Tanaman Padi. Tesis Fakultas Pascasarjana Institus Pertanian Bogor.

Rauf, A. 2010. Ekspedisi Hitam Di Sulawesi Utara. Buletin Peramalan OPT. Jatisari- Jawa Barat.

Risnandi. 2011. Kajian Perilaku Paracosmetus pallicornis di Kabupaten Wajo dan Pinrang Sulawesi Selatan. Buletin Peramalan OPT. Jatisari Juni - Jawa Barat.
Rondonuwu, S. L. 2007. Ekologi Serangga. Bahan Ajar Program Semi-Que. Fakultas Pertanian, Universitas Sam Ratulangi, Manado.

Sembel, D.T. 1991. Kepik Lygaedae (Hemiptera) pada Tanaman Padi di Kecamatan Dumoga. Suatu hama baru pada tanaman Padi.

1999. Pemantauan dan Peramalan Organisme Pengganggu di Sulawesi Utara. Laporan Hasil Penelitian. Fakultas Pertanian Unsrat.

2010. Pengendalian Hayati Serangga Hama Tropis. Gramedia. Jakarta.

Suharto, 2007. Pengenalan dan Pengendalian Hama Tanaman Pangan. Andi Yokyakarta.

Suswono, R. 2011. Sarasehan Peningkatan Produksi Beras Nasional (P2BN), Koran Kompas, edisi tanggal 31 Mei 2011. Jakarta.

Untung, K. 1993. Pengantar Pengelolaan Hama Terpadu. Gadjah Mada University Press. Yokyakarta.

Wasiati, A. 2007. Buku Pegangan Bagi Pengamat Hama Penyakit-Pengendali Organisme Pengganggu Tanaman (PHP-POPT). Direktorat Perlindungan Tanaman Pangan. Jakarta.

2009. Metode Pengamatan Organisme Pengganggu Tanaman Pangan. Direktorat Jenderal Pertanian Tanaman Pangan Jakarta.

Watung, F.W. 1996. Morfologi dan Biologi Paraeucosmetus sp. (Hemiptera: Lygaeidea) Yang Hidup Pada Tanaman Padi Dan Rumput Paspalum (Paspalum conjugatum Berg). Tesis Fakultas Pascasarjana Institut Pertanian Bogor. 
